\title{
Natural parasitism in eggs of Anticarsia gemmatalis Hübner (Lepidoptera, Noctuidae) by Trichogramma spp. (Hymenoptera, Trichogrammatidae) in Brazil
}

\author{
Marion R. F. Avanci ${ }^{1}$, Luís A. Foerster ${ }^{1,2}$ \& Carolina L. Cañete ${ }^{1,3}$
}

'Departamento de Zoologia, Universidade Federal do Paraná. Caixa Postal 19020, 81531-980 Curitiba-PR, Brazil.

${ }^{2} \mathrm{CNPq}$ fellowship.

${ }^{3}$ CAPES fellowship. Doctoral student of the postgraduate course of Zoology, UFPR.

\begin{abstract}
Aвstract. Natural parasitism in eggs of Anticarsia gemmatalis Hübner (Lepidoptera, Noctuidae) by Trichogramma spp. (Hymenoptera, Trichogrammatidae) in Brazil. Field surveys were carried during four soybean seasons in Southern Brazil to evaluate the occurrence of parasitoids in eggs of Anticarsia gemmatalis Hübner, 1818 and their incidence along the crop season. Eggs were collected by visual search on soybean leaves and from plants kept inside cages where $A$. gemmatalis moths were allowed to lay eggs. Trichogramma acacioi Brun, Moraes \& Soares, 1984 was recorded for the first time in eggs of A. gemmatalis and the citations in the literature of Trichogramma lasallei Pinto, 1998 in Brazil where based on the material collected in this survey. Apart from these species, Trichogramma pretiosum Riley, 1879, Trichogramma rojasi Nagaraja \& Nagarkatti, 1973 and Trichogramma atopovirilia Oatman \& Platner, 1983 were also collected, all of which have been previously recorded in this host. Parasitized eggs were collected all over the period of occurrence of $A$. gemmatalis, from January to April each year. Total parasitism ranged from $4.8 \%$ in 2000 and 2002 , $23.3 \%$ in 2001 and $28.9 \%$ in 2003. T. pretiosum and T. acacioi accounted for more than $80 \%$ of the parasitoids emerged each year, followed by T. atopovirilia, T. rojasi and T. lasallei, with less than $20 \%$ of incidence. Both the sex ratio and the mean number of parasitoids/egg did not differ among the species. Searching for A. gemmatalis eggs proved to be time consuming in comparison to the collection of eggs laid by moths inside the cages, which showed to be a useful method to provide qualitative estimates of parasitism in eggs of $A$. gemmatalis.
\end{abstract}

KEYWORDS. Biological control; soybeans; velvetbean caterpillar.

Resumo. Parasitismo natural em ovos Anticarsia gemmatalis Hübner (Lepidoptera: Noctuidae) por Trichogramma spp. (Hymenoptera: Trichogrammatidae) no Brasil. Levantamentos de campo foram realizados durante quatro safras de soja na região Sul do Brasil, visando avaliar as espécies de parasitóides que ocorrem em ovos de Anticarsia gemmatalis Hübner, 1818 e a incidência de parasitismo ao longo do ciclo da cultura. Os ovos foram coletados visualmente em folhas de soja e com a colocação de gaiolas em campo contendo adultos de A. gemmatalis para que realizassem oviposições. A espécie Trichogramma acacioi Brun, Moraes \& Soares, 1984 foi registrada pela primeira vez parasitando ovos de A. gemmatalis e T. lasallei Pinto, 1998 teve seu primeiro registro no Brasil através destes levantamentos. Foram também encontradas as espécies T. pretiosum Riley, 1879, T. rojasi Nagaraja \& Nagarkatti, 1973 e T. atopovirilia Oatman \& Platner, 1983, já registradas anteriormente neste hospedeiro. Ovos parasitados foram coletados durante todo o período de ocorrência de A. gemmatalis, de janeiro a março de cada ano. Os índices de parasitismo foram de 4,8\% em 2000 e $2002,23,3 \%$ em 2001 e $28,9 \%$ na safra 2003. T. pretiosum e T. acacioi foram responsáveis por mais de $80 \%$ do parasitismo nos ovos coletados a cada ano, enquanto T. atopovirilia, T. rojasi e T. lasallei, apresentaram menos de $20 \%$ de incidência. Não houve diferença significativa entre a razão sexual e o número de parasitóides emergidos por ovo hospedeiro entre as espécies de Trichogramma coletadas. A coleta de ovos naturalmente depositados foi menos eficiente em comparação à coleta de ovos depositados por fêmeas no interior das gaiolas, o qual mostrou-se um método satisfatório para a estimativa qualitativa de parasitismo em ovos de A. gemmatalis.

Palavras-Chave. Controle biológico; lagarta da soja; parasitóide de ovos.

The velvetbean caterpillar Anticarsia gemmatalis Hübner, 1818 is the most destructive noctuid attacking soybeans in Brazil. Until 1997 there was only one report on the incidence of egg parasitoids in eggs of A. gemmatalis (Hohmann et al. 1989). Polaszek \& Foerster (1997) described Telenomus cyamophylax Polaszek, 1997 from eggs of A. gemmatalis and Foerster \& Avanci (1999) reported the occurrence of Trichogramma pretiosum Riley, 1879, T. rojasi Nagaraja \& Nagarkatti, 1973 and T. atopovirilia Oatman \& Platner, 1983 parasitizing eggs of the velvetbean caterpillar.

Despite the worldwide use of Trichogramma species for the control of lepidopterous pests ( $\mathrm{Li}$ 1994), few attempts have been made in Brazil to include these species in biological control programs. Soybean pest management is underway in Brazil since the early 1970's (Kogan et al. 1975); natural control agents of velvetbean caterpillar include the entomogenous fungus Nomuraea rileyi (Farlow) Samson and the nuclear polyhedrosis virus Baculovirus anticarsia. However, the efficiency of these entomopathogens may be restricted under unfavorable climatic conditions (Moscardi 1998) and the utilization of egg parasitoids of $A$. gemmatalis has not been taken into account so far. In these circumstances the use of egg parasitoids of the genus Trichogramma would complement the action of entomopathogens in integrated control programs of the velvetbean caterpillar.

Due to the lack of knowledge on the natural incidence of 
parasitism in eggs of $A$. gemmatalis, field surveys were conducted in Paraná State, Southern Brazil during four soybean seasons, in order to identify the species of Trichogramma and to evaluate their incidence levels and relative abundance.

\section{MATERIAL AND METHODS}

Naturally laid eggs of A. gemmatalis were randomly searched on soybean leaves twice a week between January and April during the soybean seasons of 1999/00, 2000/01, 2001/02 and 2002/03 in the county of Fazenda Rio Grande

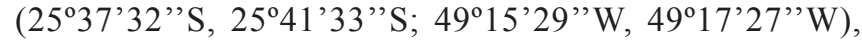
Southeastern Paraná State, Brazil. From 175 to 783 eggs were collected each year; the eggs were taken to the laboratory and individualized in gelatin capsules until parasitoid emergence.

In order to facilitate the localization of $A$. gemmatalis eggs in the plants, moths were caged on soybean plants to lay eggs. Four iron sticks $1.2 \mathrm{~m}$ high were buried $20 \mathrm{~cm}$ into the soil around the plants and a nylon cover was inserted into the sticks, standing $1 \mathrm{~m}$ above the soil with a soybean plant inside. Six couples of $A$. gemmatalis moths were released inside the cage and left to lay eggs on the plant. The mesh size of the nylon $(1 \mathrm{~mm})$ allowed access of egg parasitoids to the inside of the cage, and after three-four days the eggs found on the plants were collected and transferred to the laboratory to evaluate the incidence of parasitism, sex-ratio and number of parasitoids emerged per host egg. The number of collected and parasitized eggs was recorded, as well as the species of Trichogramma emerging from each egg. The mean number of adults emerged per host egg and the sex ratio $\left(\mathrm{N}^{\circ}\right.$. of females/ $\mathrm{N}^{\circ}$. of females $+\mathrm{N}^{\circ}$. of males) of the Trichogramma species collected in the field were determined by the pooled results obtained during the four years and sampling methods. The species of Trichogramma were identified according to morphological characters of the male genitalia (Nagaraja \& Nagarkatti 1973; Oatman \& Platner 1983). Statistical comparisons between the two methods of collection of host eggs were made by the $\chi^{2}$ test $(\mathrm{p}<0.05)$, and data on sex-ratio and number of adults emerged/host egg were submitted to Anova. On each sampling date the developmental stage of the crop was recorded (Fehr et al. 1971). The larval density of A. gemmatalis in the field was evaluated weekly by the shake cloth method in 10 points within the experimental area (Shepard et al. 1974). Voucher specimens of the Trichogramma species collected are deposited in the Coleção Entomológica "Pe. J. S. Moure", at the Departamento de Zoologia, Universidade Federal do Paraná, Brazil.

\section{RESULTS}

Apart from the species recorded by Foerster \& Avanci (1999), two other Trichogramma species were collected in A. gemmatalis eggs, namely T. acacioi Brun, Moraes \& Soares, 1984 and T. lasallei Pinto, 1998. This is the first record of $T$. acacioi in eggs of $A$. gemmatalis in Brazil and the citation of T. lasallei in Brasil by Foerster et al. (2000), Querino et al. (2000) and Querino \& Zucchi (2003) where based on the material collected in this survey.

Parasitism rates ranged from $4.8 \%$ (2000 and 2002) to $23.3 \%$ (2001), considering all eggs collected by both methods (Table

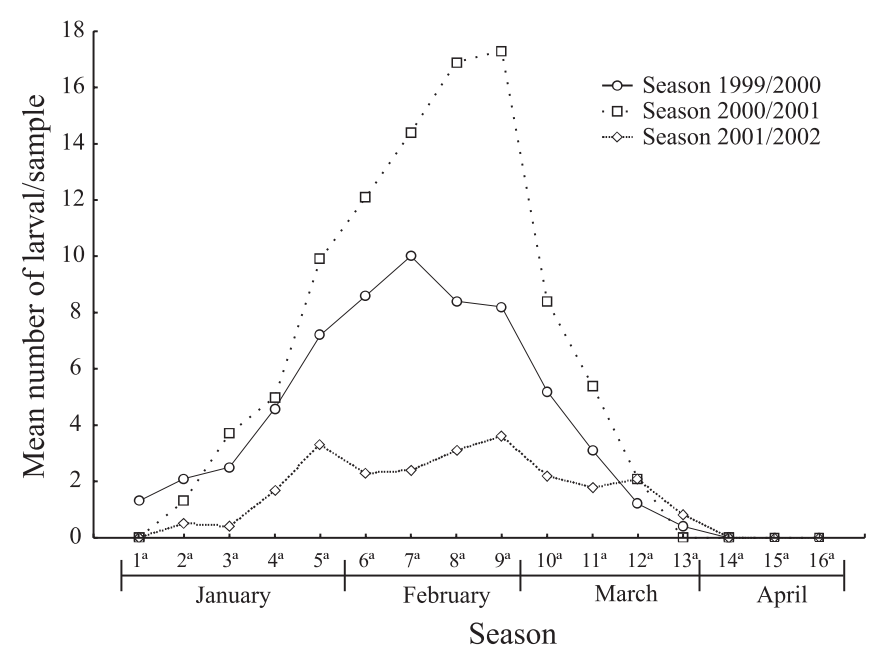

Fig. 1. Mean number of Anticarsia gemmatalis larval (large and small) sample during the 1999/2000, 2000/01 and 2001/02 soybean seasons. Fazenda Rio Grande, PR.

Table I. Total number of Anticarsia gemmatalis eggs collected by the two sampling methods and proportion of parasitized eggs. Fazenda Rio Grande, Paraná, Brazil.

\begin{tabular}{|c|c|c|c|c|c|c|c|}
\hline \multirow{2}{*}{ Season } & \multirow{2}{*}{ N. ${ }^{\circ}$ of eggs } & \multicolumn{2}{|c|}{ Cages } & \multicolumn{2}{|c|}{ Visual search } & \multicolumn{2}{|c|}{ Total } \\
\hline & & $\mathrm{N}$ & $\%$ & $\mathrm{~N}$ & $\%$ & $\mathrm{~N}$ & $\%$ \\
\hline \multirow{2}{*}{$1999 / 2000$} & Collected & 499 & & 698 & & 1197 & \\
\hline & Parasitized & 31 & $6.2 \mathrm{a}$ & 26 & $3.7 \mathrm{~b}$ & 57 & 4.8 \\
\hline \multirow{2}{*}{$2000 / 2001$} & Collected & 500 & & 783 & & 1283 & \\
\hline & Parasitized & 209 & $41.8 \mathrm{a}$ & 90 & $11.5 \mathrm{~b}$ & 299 & 23.3 \\
\hline \multirow{2}{*}{$2001 / 2002$} & Collected & 292 & & 175 & & 467 & \\
\hline & Parasitized & 12 & 4.1 & 9 & 5.1 & 21 & 4.8 \\
\hline \multirow{2}{*}{$2002 / 2003$} & Collected & $-^{2}$ & $--^{2}$ & 246 & & 246 & \\
\hline & Parasitized & $-^{2}$ & $-2^{2}$ & 71 & 28.9 & 71 & 28.9 \\
\hline
\end{tabular}

${ }^{1}$ Values followed by different letters between the two collection methods for each year differ statistically by the $\chi^{2}$ test ( $<<0.05$ ).

${ }^{2}$ Cages were not used in this season. 


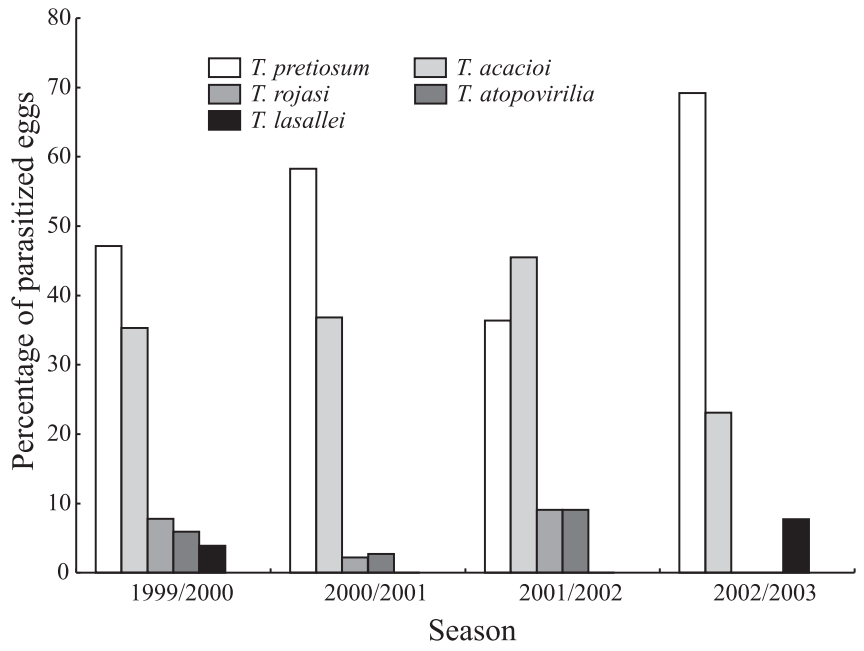

Fig. 2. Percentage of eggs of Anticarsia gemmatalis parasitized by Trichogramma species found during the 1999/2000, 2000/01, 2001/02 and 2002/03 season. Fazenda Rio Grande, Paraná, Brazil.
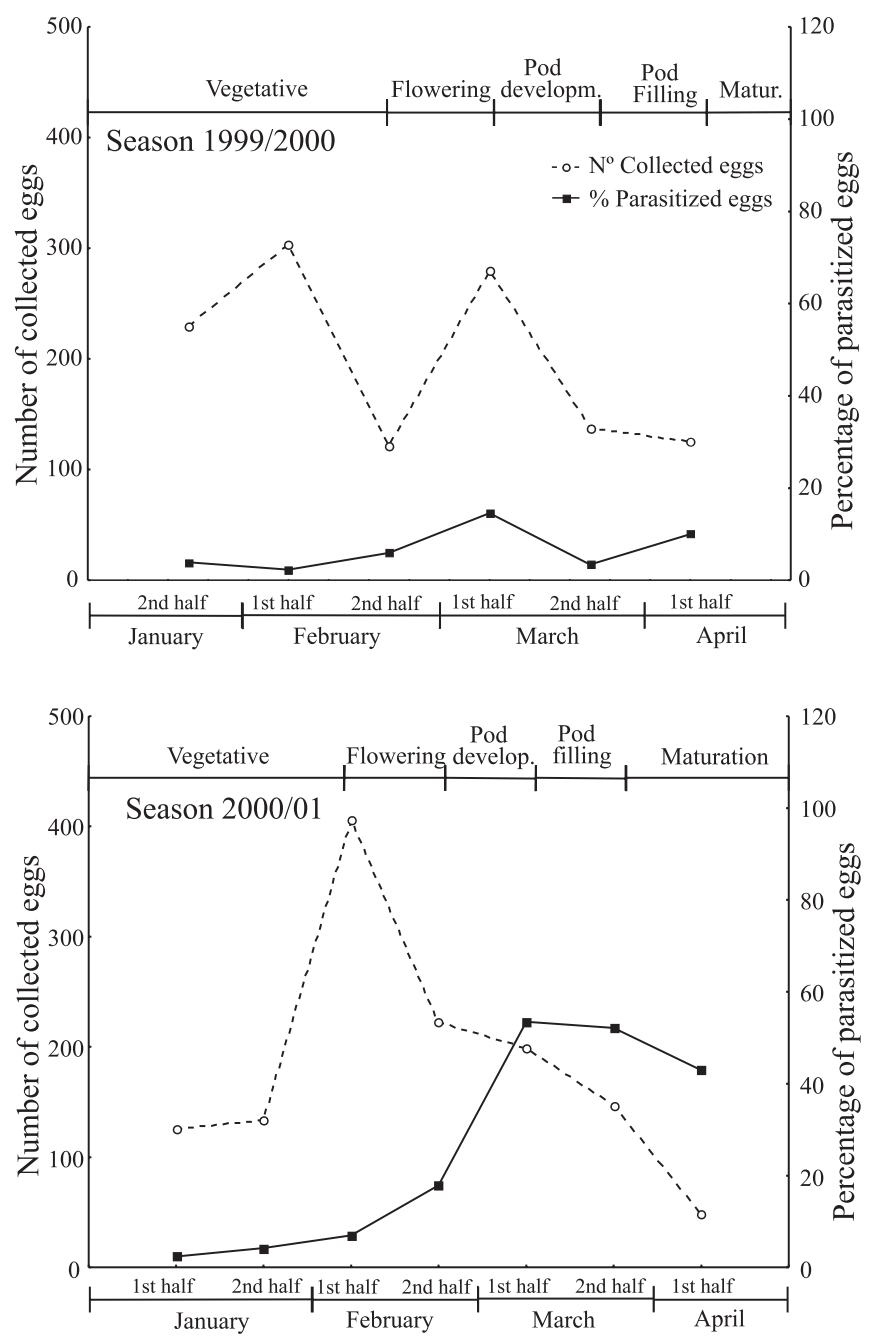

Fig. 3. Percentage of parasitism in eggs of $A$. gemmatalis and number of eggs collected during the $1999 / 2000$ and $2000 / 01$ soybean seasons. Fazenda Rio Grande, PR.
I). In 2002/03, only naturally laid eggs were collected and $28.9 \%$ of the eggs found were parasitized (Table I). Parasitism levels were related to host availability as indicated by the density of caterpillars in the crop; in 1999/2000 and 2001/02 field populations of $A$. gemmatalis larvae were well below the economic injury level established for the species (HoffmannCampo et al. 2000), whereas in 2000/01 their incidence was highest among the three years, although still below the economic threshold (Fig. 1). In 2000 and 2001 percentages of parasitism were higher in the eggs laid by moths in caged plants, while in 2002 similar parasitism rates were recorded in both cases (Table I). Eggs of $A$. gemmatalis are laid individually on stems and leaves of soybean plants and random collection is a time-consuming procedure. The release of moths in caged plants proved to be useful to detect egg parasitism and was less time-consuming than the visual search in the foliage.

Trichogramma pretiosum and T. acacioi were the predominant species, accounting for more than $80 \%$ of the parasitoids collected (Fig. 2). In Brazil, T. pretiosum is the main
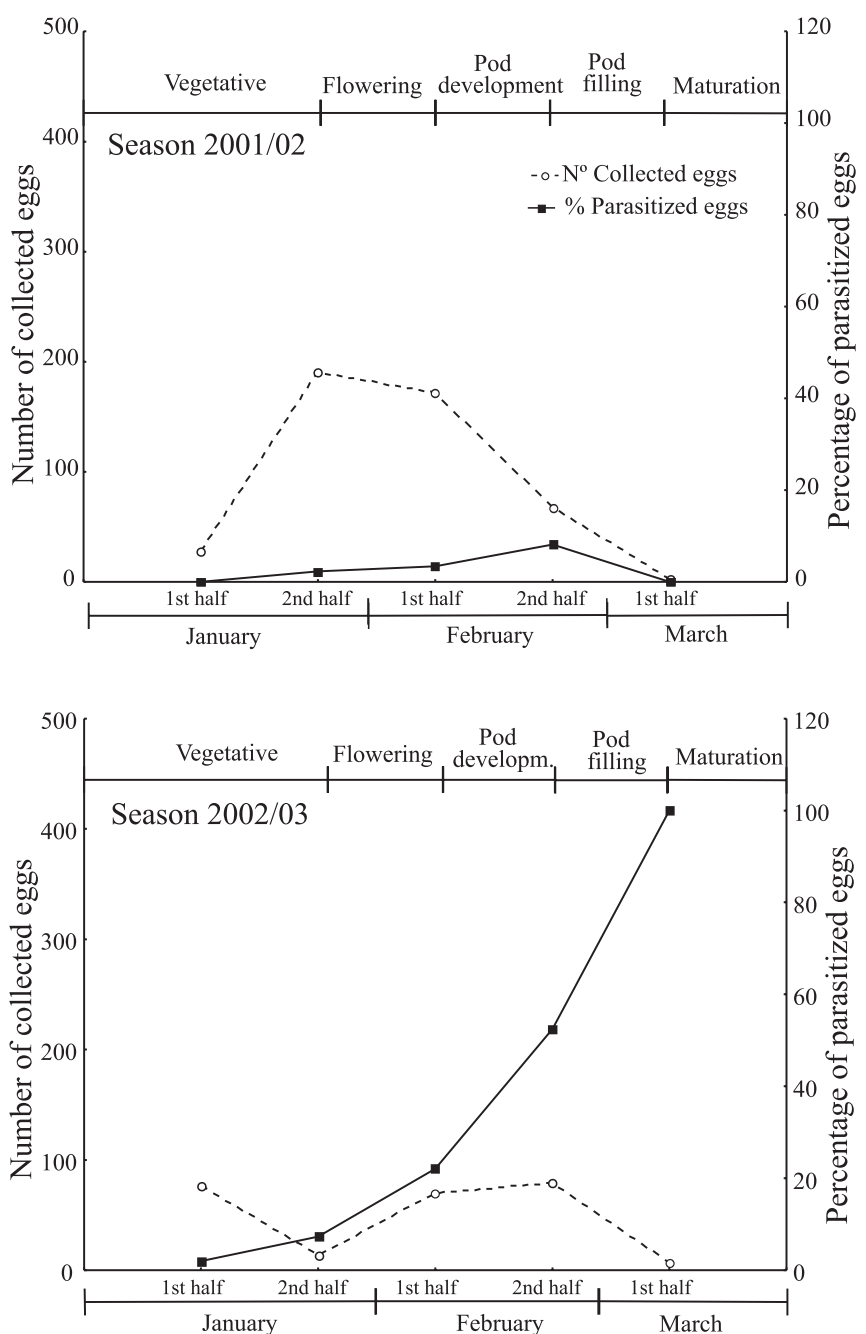

Fig. 4. Percentage of parasitism in eggs of A. gemmatalis and number of eggs collected during the 2001/02 and 2002/03 soybean seasons. Fazenda Rio Grande, PR. 
Table II. Number of parasitoids emerged, mean number $( \pm$ SE) of adults emerged per host egg and sex- ratio of Trichogramma species. Fazenda Rio Grande, Paraná, Brazil.

\begin{tabular}{lcccc}
\hline \multicolumn{1}{c}{ Species } & $\mathrm{N}$ & $\mathrm{N}^{\mathrm{o}}$ parasitoids emerged & Adults emerged / host egg & Sex-ratio $^{1}$ \\
\hline T. pretiosum & 168 & 376 & $2.2 \pm 0.06 \mathrm{NS}^{2}$ & $0.69 \pm 0.02 \mathrm{NS}^{2}$ \\
T. acacioi & 114 & 256 & $2.3 \pm 0.07$ & $0.73 \pm 0.03$ \\
T. rojasi & 11 & 30 & $2.7 \pm 0.19$ & $0.71 \pm 0.05$ \\
T. atopovirilia & 11 & 25 & $2.3 \pm 0.19$ & $0.70 \pm 0.06$ \\
T. lasallei & 3 & 6 & $2.0 \pm 0.58$ & $0.89 \pm 0.11$ \\
\hline
\end{tabular}

${ }^{1}$ Sex-ratio $=\mathrm{n}^{\mathrm{o}}$ de fêmeas $/ \mathrm{n}^{\mathrm{o}}$ de machos $+\mathrm{n}^{\mathrm{o}}$ de fêmeas

${ }^{2}$ Means did not differ statistically for the number of adults emerged/host egg $(F=1.28$; d.f. $=4$; $p<0,05)$ and for the sex-ratio $(F=0.68$; d.f. $=4$; $\mathrm{p}<0,05)$.

parasitoid in eggs of Lepidoptera (Zucchi \& Monteiro 1997), while $T$. acacioi has not been previously cited in eggs of $A$. gemmatalis.

Parasitoids were present in the crop since the first sampling date in January in the vegetative stage of the crop (Figs. 3, 4). Natural oviposition by adults of $A$. gemmatalis lasted until the end of March at pod-filling, when no more eggs were found in the crop. However eggs laid by caged moths in April were found parasitized, indicating that adults of Trichogramma were still present in the crop after the period of natural incidence of the host. Parasitism rates increased as the soybean season progressed, reaching the highest percentages during the development and filling of the pods in all seasons.

The mean number of adult parasitoids emerged per host egg and the sex-ratio of each species are shown in Table II. More adults of $T$. rojasi emerged from A. gemmatalis eggs in comparison to the other species, but the differences were not significant. Also, no statistical differences were recorded in the sex-ratio of the Trichogramma species collected in the field, which ranged from 0.69 in T. pretiosum to 0.89 in $T$. lasallei.

The high rates of parasitism observed in 2000/01 show that egg parasitoids may have a significant impact on the natural control of the velvetbean caterpillar, provided selective insecticides are used judiciously against soybean insect pests. From the results, it is concluded that T. pretiosum and T. acacioi are the most promising species to be considered in massrearing programmes for the biological control of VBC in Brazil.

Acknowledgements. The authors are grateful to Dr. Roberto R. Zucchi of the Universidade de São Paulo and Ranyse B. Querino of the Instituto Nacional de Pesquisas da Amazônia (INPA) for the identification of T. acacioi and T. atopovirilia, and to Dr. John Pinto of the University of California for the identification of T. rojasi and $T$. lassallei. This research was conducted with financial support of the Conselho Nacional de Desenvolvimento Científico e Tecnológico $(\mathrm{CNPq})$ and Fundação Araucária, to which the authors are grateful.

\section{REFERENCES}

Fehr, W. R.; C. E. Caviness; D. T. Burmood \& J. S. Pennington. 1971. Stage of development description for soybeans, Glycine $\max (\mathrm{L}$. Merril. Crop Science 11: 929-931.
Foerster, L. A. \& M. R. F. Avanci. 1999. Egg parasitoids of Anticarsia gemmatalis Hübner (Lepidoptera: Noctuidae) in soybeans. Anais da Sociedade Entomológica do Brasil 28: 545-548.

Foerster, L. A.; M. R. F. Avanci; J. M. R. Martins \& C. L. Cañete. 2000. Egg parasitoids of Anticarsia gemmatalis (Lepidoptera: Noctuidae) on soybeans in Brazil. Abstracts of International Congress of Entomology. Londrina, CNPSoja, p. 385.

Hohmann, C. L.; S. M. T Silva \& W. J. Santos. 1989: Lista preliminar de Trichogrammatidae encontrados no Paraná. Anais da Sociedade Entomológica do Brasil 18: 203-206.

Hoffmann-Campo, C. B.; F. Moscardi; B. S. Corrêa-Ferreira; L. J. Oliveira; D. R. Sosa-Gómez; A. R. Panizzi; I. C. Corso; D. L. Gazzoni \& E. B. Oliveira. 2000. Pragas da soja no Brasil e seu manejo integrado. Londrina: Embrapa Soja. 70p. (Circular Técnica/EMBRAPA Soja, n. 30).

Kogan, M.; S. G. Turnipseed; M. Shepard; E. B. Oliveira \& A. Borgo. 1975: Pilot insect pest management program for soybean in Southern Brazil. Journal of Economic Entomology 70: 659663.

Li, L. Y. 1994. Worldwide use of Trichogramma for biological control on different crops: A survey. p. 37-51. In: E. Wajnberg \& S. A. Hassan (eds.), Biological control with egg parasitoids. CAB International, $286 \mathrm{p}$.

Moscardi, F. 1998. Utilização de vírus entomopatogênicos em campo, p. 509-539. In: S. B. Alves (ed.). Controle microbiano de insetos. São Paulo, FEALQ, 407 p.

Nagaraja, H. \& S. Nagarkatti. 1973. A key to some New World species of Trichogramma (Hymenoptera: Trichogrammatidae), with descriptions of four new species. Proceedings of the Entomological Society of Washington 75: 288-297.

Oatman, E. R. \& G. R. Platner. 1983. A new species of Trichogramma (Hymenoptera: Trichogrammatidae), with notes on other species collected in Guatemala. Proceedings of the Entomological Society of Washington 85: 710-713.

Polaszek, A. \& L. A. Foerster. 1997. Telenomus cyamophylax, n. sp. (Hymenoptera: Scelionidae) attacking eggs of the velvetbean caterpillar, Anticarsia gemmatalis Hübner (Lepidoptera: Noctuidae). Anais da Sociedade Entomológica do Brasil 26: 177-181.

Querino, R. B. \& R. A. Zucchi. 2003. Caracterização morfológica de dez espécies de Trichogramma (Hymenoptera: Trichogrammatidae) registradas na América do Sul. Neotropical Entomology 32: 597617.

Querino, R. B.; R. A. Zucchi; A. I. Ciociola Jr.; C. L. Cañete \& L. A. Foerster. 2000. Characterization of three species of the genus Trichogramma. Abstracts of International Congress of Entomology. Londrina, CNPSoja, p. 411.

Shepard, M.; G. R. Carner \& S. G. Turnipseed. 1974. A comparasion of three sampling methods for arthropods in soybean. Environmental Entomology 3: 227-232.

Zucchi, R. A. \& R. C. Monteiro. 1997. O gênero Trichogramma na América do Sul, p. 183-205. In: J. R. P. Parra \& R. A. Zucchi (eds.). Trichogramma e o controle biológico aplicado. Piracicaba, FEALQ, $324 \mathrm{p}$. 